\title{
Differential expression of complement proteins and regulatory decay accelerating factor in relation to differentiation of cultured human colon adenocarcinoma cell lines
}

\author{
M-F Bernet-Camard, M-H Coconnier, S Hudault, A L Servin
}

\begin{abstract}
Self protection of host cells against inadvertent injury resulting from attack by autologous complement proteins is well reported for vascular epithelium. In intestinal epithelium, the expression of C complement proteins and regulatory proteins remains currently poorly reported. This study looked at the distribution of $C$ complement proteins and regulatory decay accelerating factor (DAF) in four cultured human intestinal cell lines of embryogenic or colon cancer origins. C3 and C4 proteins and DAF were widely present in human colon adenocarcinoma $\mathbf{T}_{84}, \mathrm{HT}-29 \mathrm{glc}^{-1+}$ cells compared with human embryonic INT407 cells. In contrast, no expression of C5, C5b-9, and CR1 was seen for any of the cell lines. Taking advantage of the Caco-2 cells, which spontaneously differentiate in culture, it was seen that the C3, C4, and DAF were present in undifferentiated cells and that their expression increased as a function of the cell differentiation. These results, taken together with other reports on the presence of $\mathrm{C}$ complement proteins and DAF in the intestinal cells infer that the expression of regulatory $C$ complement proteins develops in parallel with the expression of $C$ proteins to protect these cells against the potential injury resulting from the activation of these local $\mathrm{C}$ proteins. Moreover, the finding that the pathogenic C1845 Escherichia coli binds to the membrane bound DAF in the cultured human intestinal cells synthetising locally $C$ proteins and regulatory $C$ proteins supports the hypothesis that $E$ coli could promote inflammatory disorders by blocking local regulatory protein function.

(Gut 1996; 38: 248-253)
\end{abstract}

Keywords: inflammatory disorders, enterocytic differentiation, decay accelerating factor, human intestinal cells, diffusely adhering $E$ coli.

It has been well reported that the activation of the complement system with and without the loss of the complement regulatory proteins would augment inflammation by allowing host complement to damage host cells. Human cells are protected from homologous $\mathrm{C}$ attack by expressing $\mathrm{C}$ regulatory proteins. In particular, decay accelerating factor (DAF - CD55), a glycosylphosphatidylinositol anchored glycoprotein (GPI) present on epithelial cells lining the vascular compartment, protects these cells from potential injury arising from attacks by autologous complement proteins by regulating the activity of both the classic and alternative complement pathways $\mathrm{C} 3$ and $\mathrm{C} 5$ convertases. ${ }^{1}$

DAF is present in extravascular cells and in these cells its function remains unknown. Expression of the $\mathrm{C} 3$ and C4 complement proteins has been reported in cultured human adenocarcinoma Caco-2 cells ${ }^{2}{ }^{3}$ and their synthesis is regulated by cytokines. ${ }^{2}$ Very few studies have shown the presence of DAF in human intestinal cells. ${ }^{4}$ Our previous studies suggest, however, that this regulatory protein could be expressed by several cultured human colon adenocarcinoma cells. Indeed, we have seen that the cultured human adenocarcinoma HT-29 and Caco-2 cells can be infected by Escherichia coli bearing the fimbrial F1845 adhesin, Dr haemagglutinin or afimbrial AFAI adhesin, ${ }^{56}$ which recognise in erythrocytes the Dr receptor, ${ }^{78}$ a part of the DAF. ${ }^{9}$

The aim of this study was to examine the comparative expression of several C complement proteins and DAF by the cultured human intestinal cells. As cells in the intestine differentiate along the crypt-villus axis, ${ }^{10}$ we used a subset of cultured human intestinal cell lines expressing different states of differentiation $^{1112}$ to approach in vitro this dynamic situation.

\section{Methods}

\section{Cell culture}

HT-29 $\mathrm{glc}^{-/+}$and Caco-2 cells were a gift from A Zweibaum (INSERM Unité 178, Villejuif, France). The enterocytic Caco-2 cells ${ }^{13}$ spontaneously differentiate in culture under standard conditions - that is, in a standard glucose containing medium. The enterocytic HT-29 glc $^{-1+}$ cells $^{14}$ are a subpopulation obtained from the parental, mainly undifferentiated HT-29 standard cell line ${ }^{15}$ by selection through glucose deprivation ${ }^{16}$ reversion back to a standard glucose containing medium. HT$29 \mathrm{glc}^{-1+}$ and Caco-2 cells were routinely grown in Dulbecco modified Eagle's minimal essential medium (DMEM) (25 mM glucose) (Eurobio, Paris, France), supplemented with $10 \%\left(\mathrm{HT}-29 \mathrm{glc}^{-/+}\right)$or $20 \%$ (Caco-2) 
inactivated $\left(30 \mathrm{~min}, 56^{\circ} \mathrm{C}\right.$ ) fetal calf serum (Boehringer, Mannheim, Germany) and 1\% non-essential amino acids (Caco-2) at $37^{\circ} \mathrm{C}$ in a $10 \% \mathrm{CO}_{2} / 90 \%$ air atmosphere. Cells were seeded at a concentration of $10^{5}$ (HT-29 $\mathrm{glc}^{-1+}$ ) and $7 \cdot 4 \times 10^{4}(\mathrm{Caco}-2)$ cells per $\mathrm{cm}^{2}$. For maintenance purposes, cells were passaged weekly using $0.25 \%$ trypsin in $\mathrm{Ca}^{2+} \mathrm{Mg}^{2+}$ free phosphate buffered saline (PBS) containing $0.53 \mathrm{mM}$ EDTA. Unless otherwise stated, cells were used for adherence assays at late post-confluence - that is, after 15 days (Caco2) and 20 days (HT-29 $\mathrm{glc}^{-/+}$) in culture. For time course, Caco-2 cells were used after 5 days, 10 days, and 15 days in culture.

$\mathrm{T}_{84}$ cells were from $\mathrm{K}$ Dharmsathaphorn (University of California, San Diego, CA). ${ }^{17} 18$ Cells were routinely grown in DMEM (50\%) and Ham's F12 (50\%) supplemented with 2 $\mathrm{mM}$ glutamine, $50 \mathrm{mM}$ HEPES, $1 \%$ nonessential amino acids, and $10 \%$ inactivated (30 min, $56^{\circ} \mathrm{C}$ ) fetal calf serum (Boehringer, Mannheim, Germany) at $37^{\circ} \mathrm{C}$ in a $10 \%$ $\mathrm{CO}_{2} / 90 \%$ air atmosphere. Cells were seeded at a concentration of $10^{6}$ cells per $\mathrm{cm}^{2}$. Cells were used for adherence assays at late post-confluence - that is, after 10 days.

INT407 cells (human embryonic intestine; ATCC CCL 6) were from a stock culture of the American Type Culture Collection (Rockville, MD). Cells were cultured in DMEM supplemented with $1 \%$ non-essential amino acids and $10 \%$ inactivated $(30 \mathrm{~min}$, $56^{\circ} \mathrm{C}$ ) fetal calf serum (Boehringer, Mannheim, Germany) at $37^{\circ} \mathrm{C}$ in a $10 \%$ $\mathrm{CO}_{2} / 90 \%$ air atmosphere. Cells were used for adherence assays at confluence - that is, after four days.

\section{Antibodies}

The mouse monoclonal CY-DAF antibody raised against human DAF was from Valbiotech (France). The rabbit polyclonal antihuman C5 fluorescein coupled antibody F255, the antihuman C5b-9 mAb M777, and the antihuman CR1 (CD35) mAb M710 were purchased from Dako (Denmark). The rabbit polyclonal C-7761 antihuman complement C3 antibody and the rabbit polyclonal C-3402 antihuman complement C4 antibody were from Sigma Chemical Company (St Louis, USA). The ascites fluid containing antibody HBB 2/614/88 against human sucrase-isomaltase (SI) was a gift from Hauri HP (Biocentre of the University of Basle, Switzerland). The ascites fluid containing antibody $4 \mathrm{H} 3$ against human dipeptidylpeptidase IV (DPP IV) was obtained from Maroux S (Centre de Biochimie et de Biologie Moléculaire, Marseilles, France). The ascites fluid containing antibody HBB2/45 against aminopeptidase $\mathrm{N}$ (ApN) was from Quaroni A (Cornell University, Ithaca, USA). Anticarcinoembryogenic antigen (CEA) mAb 517 was obtained from Le Bivic A (URA 179 CNRS, Marseilles).

Immunofluorescence

Indirect immunofluorescence was performed on unpermeabilised cell layers as previously reported. ${ }^{5}$ Preparations were fixed for 10 minutes at room temperature in $3.5 \%$ paraformaldehyde in PBS. Cell monolayers were incubated with specific primary antibody for 30 minutes at room temperature, washed, and then incubated with their respective secondary fluorescein conjugated antibody. Primary antibodies were diluted 1:50-200 in PBS (CY-DAF, 1:50; anti-C5 F-255, 1:50; anti-C3 C-7761, 1:50; anti-C4 C-3402, 1:50; anti-C5b-9 M777, 1:50; antihuman CR1 M710, 1:50; anti-SI HBB 2/614/88, 1:200; anti-DPP IV 4H3, 1:50, anti-ApN HBB2/45, $1: 50$, and anti-CEA $517,1: 50$ ) in $2 \%$ bovine serum albumin (BSA) PBS. Secondary antibodies were either fluorescein or rhodamine conjugated goat antimouse IgG from Immunotech (Luminy, France), and fluorescein conjugated goat antirabbit IgG from Institut Pasteur Productions (Paris, France), used at a dilution of $1: 20$ in $2 \%$ BSA-PBS. No fluorescent staining was seen when nonimmune serum was used and when the primary antibody was omitted. Immunolabelling was examined using a Leitz Aristoplan microscope with epifluorescence. All photographs were taken on Kodak T-MAX 400 black and white film (Eastman Kodak, Rochester, NY).

\section{Scanning and electron microscopy}

For scanning electron microscopy, the intestinal cells were grown on glass coverslips. Cells were fixed with $2.5 \%$ glutaraldehyde in $0.1 \mathrm{M}$ phosphate buffer $(\mathrm{pH} 7 \cdot 4)$ at $24^{\circ} \mathrm{C}$ for one hour. After five washes with phosphate buffer, cells were post-fixed for 30 minutes with $2 \%$ osmium tetroxide and washed three times with the $0.1 \mathrm{M}$ phosphate buffer. Cells were dried after substitution of buffer with liquid carbon dioxide (Balzers CPD030, Hudson, NH) and coated with gold. The specimens were then examined with a Jeol JSM 25S scanning electron microscope.

\section{Bacterial strains, growth conditions, and} radiolabelling

The diffusely adhering $E$ coli (DAEC) $\mathrm{C} 1845$ harbouring the fimbrial F1845 adhesin was grown on CFA-agar containing $1 \%$ Casamino Acids (Difco Laboratories, Detroit, MI), $0.15 \%$ yeast extract, $0.005 \%$ magnesium sulphate, and $0.0005 \%$ manganese chloride in $2 \%$ agar for 18 hours at $37^{\circ} \mathrm{C} .^{5}$

\section{Cell infection conditions}

Quantitative binding assay entailing the incubation of a fixed concentration of $E$ coli $\left(10^{8}\right.$ $\mathrm{CFU} / \mathrm{ml}$ ), metabolically labelled by the addition of ${ }^{14} \mathrm{C}$-acetic acid (Amersham, 94 $\mathrm{mCi} / \mathrm{mmol} ; 100 \mu \mathrm{Ci} / 10 \mathrm{ml}$ tube) with cultured cells, was performed as previously described. ${ }^{6}$ Briefly, the cell monolayers were washed twice with PBS. Radiolabelled $E$ coli were suspended in the culture medium without antibiotic, and a total of $1 \mathrm{ml}\left(10^{8}{ }^{14} \mathrm{C}\right.$-labelled cells $\left./ \mathrm{ml}\right)$ of this suspension was added to each well of the 

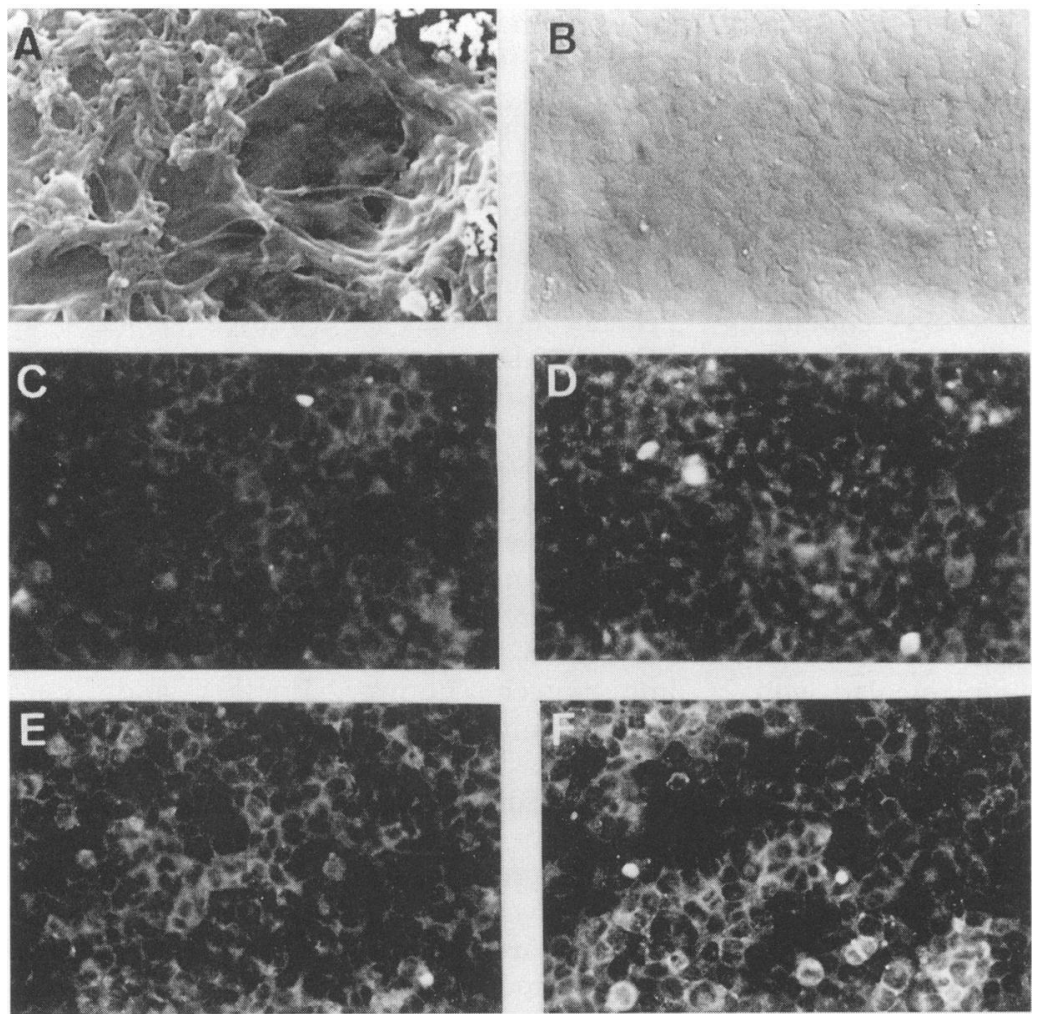

Figure 1: Expression of $C 3$ and C4 complement proteins, and DAF in human cultured intestinal INT407 cells. (A) High magnification scanning electron micrograph of confluent cells showing the disorganised cell surface with long bulges. Magnification $\times 10000 .(B)$ Interference contrast micrograph of cells, magnification $\times 40$. (C to F) showing indirect immunofluorescence labelling of DPP IV (C), C3 (D), C4 (E), and DAF (F). Note the absence of immunolabelling for DPP IV and the low level and faint immunofluorescence labelling localised to the cell to cell contact for $C 3$ and C4. In contrast, the immunofluorescence labelling of $D A F$ at the cell to cell contact was considerably pronounced.

TABLE I Expression of $C$ proteins, $C R 1, D A F$, and differentiation associated markers by human cultured intestinal INT407, $T_{84}, H T-29 \mathrm{glc}^{-1+}$, and Caco-2 cells

\begin{tabular}{|c|c|c|c|c|}
\hline & INT407 & $T_{84}$ & $H T-29 g c^{-1+\star}$ & Caco-2† \\
\hline $\begin{array}{l}\text { Differentiation markers } \\
\text { Sucrase-isomaltase } \\
\text { Dipeptidylpeptidase IV } \\
\text { Aminopeptidase neutre } \\
\text { CEA }\end{array}$ & $\begin{array}{l}\text { Negative } \\
\text { Negative } \\
\text { Negative } \\
\text { Positive }\end{array}$ & $\begin{array}{l}\text { Negative } \\
\text { Positive } \\
\text { Low positive } \\
\text { Positive }\end{array}$ & $\begin{array}{l}\text { Negative } \\
\text { Positive } \\
\text { Low positive } \\
\text { Positive }\end{array}$ & $\begin{array}{l}\text { Positive } \\
\text { Positive } \\
\text { Low positive } \\
\text { Positive }\end{array}$ \\
\hline $\begin{array}{l}\text { Complement C3 } \\
\text { Complement C4 } \\
\text { Complement C5 } \\
\text { Complement C5b-9 } \\
\text { CR1 } \\
\text { DAF }\end{array}$ & $\begin{array}{l}\text { Low positive } \\
\text { Low positive } \\
\text { Negative } \\
\text { Negative } \\
\text { Negative } \\
\text { Low positive }\end{array}$ & $\begin{array}{l}\text { Positive } \\
\text { Positive } \\
\text { Negative } \\
\text { Negative } \\
\text { Negative } \\
\text { Positive }\end{array}$ & $\begin{array}{l}\text { Positive } \\
\text { Positive } \\
\text { Negative } \\
\text { Negative } \\
\text { Negative } \\
\text { Positive }\end{array}$ & $\begin{array}{l}\text { Positive } \\
\text { Positive } \\
\text { Negative } \\
\text { Negative } \\
\text { Negative } \\
\text { Positive }\end{array}$ \\
\hline
\end{tabular}

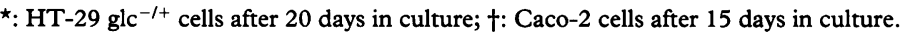

tissue culture plate. Adherence assays were performed in the presence of $1 \%$ mannose to block the non-specific attachment of the bacteria by type 1 fimbriae to the cells. The plates were incubated at $37^{\circ} \mathrm{C}$ in $10 \%$ carbon dioxide $/ 90 \%$ air for one hour. The monolayers were then washed three times with sterile PBS. Adhering bacteria and intestinal cells were dissolved in a $0 \cdot 2 \mathrm{~N} \mathrm{NaOH}$ solution. The level of bacterial adhesion was evaluated by liquid scintillation counting. Inhibition of adhesion was conducted using anti-DAF mAb CY-DAF (diluted 1:20 in PBS). Cells were treated with $4 \mathrm{mg} / \mathrm{ml}$ phosphatidylinositol specific phospholipase C (PIPLC, Sigma Chemical Company, St Louis, USA) for 60 minutes at $37^{\circ} \mathrm{C}$ before incubating with $E$ coli. Each adherence assay was conducted in duplicate with three successive cell passages.

\section{Results}

Expression of complement proteins and DAF in cultured human intestinal cell lines

We examined the expression of $C$ complement proteins and regulatory DAF in INT407, $\mathrm{T}_{84}$, and HT-29 $\mathrm{glc}^{-1+}$, in parallel with the expression of differentiation associated intestinal markers; SI, DPP IV, ApN, and carcinoembryogenic antigen CEA.

Currently, the morphological and functional characteristics of the human embryonic intestinal INT407 cells are not reported. Observation by scanning electron microscopy of the cell surface showed no brush border, which is the principal morphological characteristic of differentiated intestinal cells. These cells exhibit an absence of expression of differentiation marker DPP IV (Fig 1), SI, and $\mathrm{ApN}$, whereas expression of CEA was seen (Table I). These results show that INT407 cells are undifferentiated. C3 and C4 complement proteins were expressed at a low level by the INT407 cells, and the faint labelling seemed localised to the cell to cell contacts. No expression of $\mathrm{C} 5$ and $\mathrm{C} 5 \mathrm{~b}-9$ proteins was seen. In contrast, a pronounced expression of DAF was found.

The $\mathrm{T}_{84}$ cells $^{1718}$ do not differentiate toward the villus-like state; these cells express functional properties of colon crypt cells. ${ }^{19}$ Observation of the $T_{84}$ cells by scanning electron microscopy showed rudimentary microvilli sparsely distributed at their apical domain (Fig 2). Staining of DPP IV and CEA in $T_{84}$ cells showed a high level of expression of these proteins, and the mosaic pattern showed variable intensities in expression among the cells (Fig 2). In contrast, ApN was sparsely expressed, whereas SI was not expressed at all. DAF was intensely expressed in a mosaic pattern, whereas the $\mathrm{C} 3$ and $\mathrm{C} 4$ complement proteins were highly expressed in a diffuse pattern with randomly distributed pronounced patches. No C5, C5b-9, and CR1 expression occurred in $\mathrm{T}_{84}$ cells.

The HT-29 glc $^{-1+}$ cell subpopulation ${ }^{14}$ expressed structural and functional differentiation characteristics similar to those of the mature enterocyte of the small intestine. ${ }^{10-12}$ Scanning electron microscopy of the HT-29 $\mathrm{glc}^{-1+}$ cells show the presence of tall and regular microvilli uniformly distributed and forming a dense and well organised brush border, which carpets the apical surface (Fig 3). These cells widely expressed the DPP IV and CEA, expressed little ApN, and lacked SI, the last because in these cells the SI expression is inhibited by the presence of glucose in the culture medium. ${ }^{11}$ The C3 complement protein and the DAF were intensely expressed by HT-29 glc $^{-1+}$ cells. In contrast, a low expression of $\mathrm{C} 4$ protein was evident. As for $\mathrm{T}_{84}$ cells, no $\mathrm{C} 5, \mathrm{C} 5 \mathrm{~b}-9$, and $\mathrm{CR} 1$ positive immunoreactivity was detected.

As summarised in Table I, the undifferentiated INT407 cells expressed a low level of C complement proteins and regulatory DAF. In contrast, such proteins were widely expressed in the $T_{84}$ colonic crypt cells and in the fully 
differentiated colon carcinoma HT-29 $\mathrm{glc}^{-1+}$ cells. These results suggested that the expression of $\mathrm{C} 3, \mathrm{C} 4$, and DAF could evolve as a function of cell differentiation.
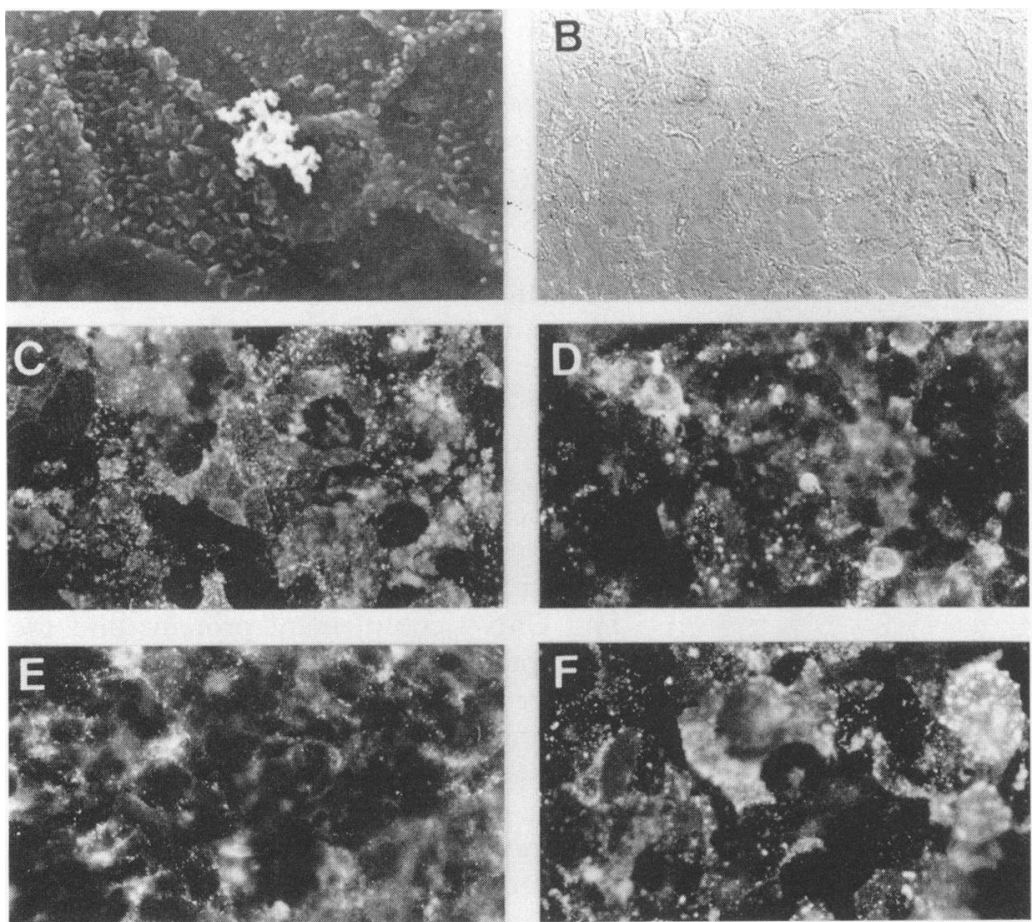

Figure 2: Expression of $C 3$ and $C 4$ complement proteins, and DAF in human cultured intestinal $T_{8}$ crypt cells. (A) Low magnification scanning electron micrograph of confluent cells. Note the octagonal cell organisation with well marked cell to cell contacts and the presence of sparsely distributed short microvilli. Magnification $\times 5000$. (B) Interference contrast micrograph of cells. (C to F) showing indirect immunofluorescence labelling of DPP IV (C), C3 (D), C4 (E), and DAF (F) in unpermeabilised cells (magnifications $\times 40)$. Note the high expression of DPP IV and DAF in a mosaic pattern. In contrast, $C 3$ and $C 4$ are expressed diffusely and in intense patches.
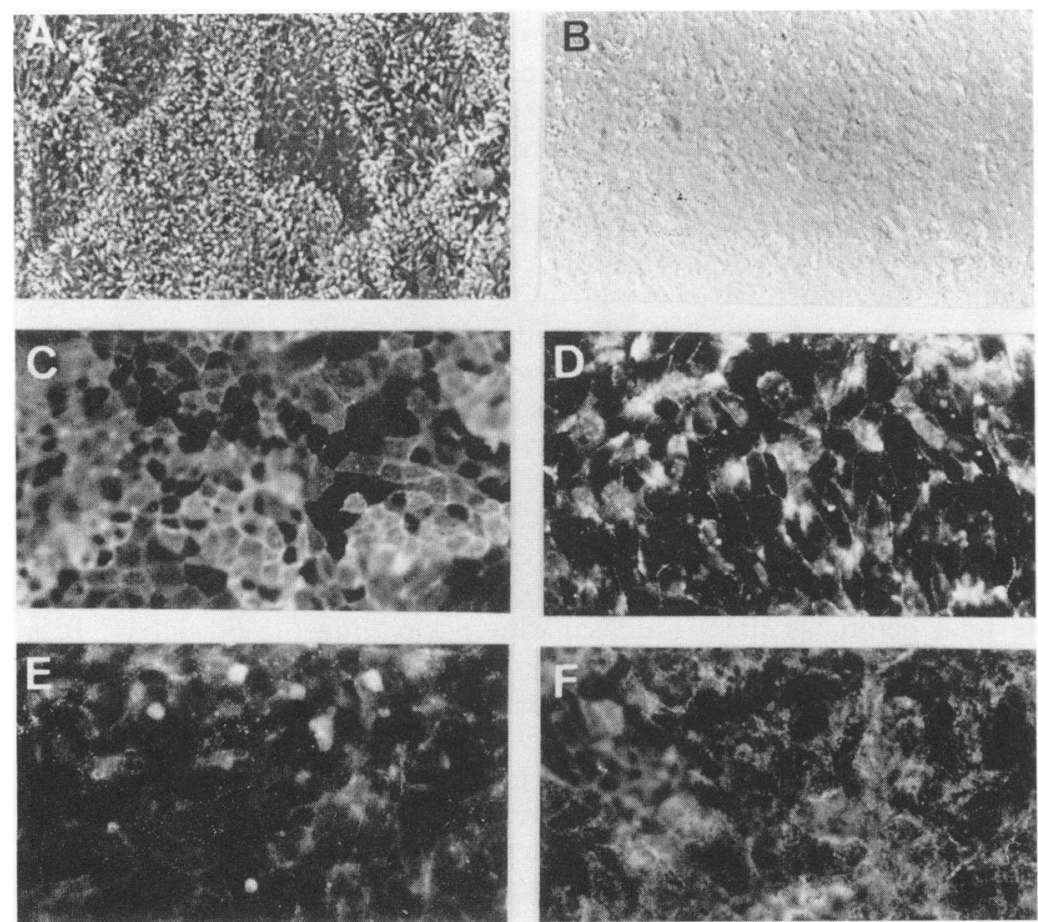

Figure 3: Expression of $C 3$ and $C 4$ complement proteins and DAF by the human cultured intestinal HT-29 $\mathrm{glc}^{-1+}$ cell subpopulation. (A) Low magnification scanning electron micrograph of confluent cells. Note the presence of well organised and dense microvilli. Magnification $\times 2000$. (B) Interference contrast micrograph of confluent cells. (C to $F)$ showing indirect immunofluorescence labelling of DPP IV (C),C3 (D), C4 (E), and $D A F(F)$ in unpermeabilised cells (magnifications $\times 40)$. Note the high expression of DPP $I V$ in a mosaic pattern. $C 3$ and DAF were expressed diffusely and in intense patches, whereas $C 4$ was expressed at a low level.
Expression of $C 3$ complement protein and $D A F$ as a function of the intestinal cell differentiation

In the intestine a rapid epithelial cell renewal occurs and the cells differentiate along the crypt-villus axis. ${ }^{1112}$ To approach in vitro the dynamic situation of the intestine, we took advantage of the Caco- 2 cells, which spontaneously differentiate in culture. ${ }^{13}$ Time course of appearance of $\mathrm{C} 3$ and DAF was determined in Caco-2 cells as a function of the days in culture together with the differentiation marker SI (Fig 4). The proportion of SI positive cells increased progressively with the age of the culture, consistent with the well reported growth related expression of intestinal brush border hydrolases. ${ }^{11}$ The $\mathrm{C} 3$ complement protein and DAF were expressed by Caco- 2 cells perpetually in culture in a diffuse pattern. When examined in relation to the time course of differentiation, we found that the level of expression of $\mathrm{C} 3$ complement protein and DAF increased in parallel with differentiation. The same result was obtained for the C4 protein (not shown). As for HT-29 $\mathrm{glc}^{-1+}$ cells and $\mathrm{T}_{84}$ cells, no $\mathrm{C} 5, \mathrm{C} 5 \mathrm{~b}-9$, and CR1 positive immunoreactivity was detected in Caco- 2 cells at any period of culture.

\section{$D A F$ acts as receptor for the diarrhoeagenic}

C1845 E coli in cultured human intestinal cells The diarrhoeagenic C1845 E coli bearing the fimbrial F1845 adhesin binds equally to the undifferentiated INT407, the poorly differentiated $T_{84}$, and the fully differentiated Caco- 2 cells (Table II). Significant inhibition of adhesion was obtained by incubating the cells and the bacteria with the anti-DAF mAb CY-DAF, although the effect was comparatively less prominent in $\mathrm{T}_{84}$ and Caco- 2 cells than in INT407 cells. In Caco-2 cells, the inhibition of the $\mathrm{C} 1845$ binding by anti-DAF antibody is not significantly different from the inhibition obtained with anti-F1845 antibody. To analyse how the DAF is anchored to the cell membrane of cultured human intestinal cells, we treated the cells with PIPLC. A high level of inhibition of the $E$ coli binding was seen in INT407 cells after PIPLC treatment, whereas in $\mathrm{T}_{84}$ and Caco-2 cells the inhibition was less pronounced.

\section{Discussion}

Defect of C complement regulatory proteins and blockage of their regulatory functions renders the host cells sensitive to inadvertent local complement mediated damage. ${ }^{20-22}$ Human cells exposed to abundant plasma C sources are protected from homologous C attack by expressing C regulatory proteins. ${ }^{123} 24$ Among these, membrane DAF and MCP, and plasma factors are responsible for self protection against classic and alternative pathways of homologous C. ${ }^{123} \mathrm{~A}$ local synthesis of $\mathrm{C}$ components occurs in extravascular non-intestinal epithelial cells. ${ }^{25-28}$ In the case of the intestine, regulatory DAF is present in cells lining the epithelium, ${ }^{4}$ and in cultured human intestinal cells synthesis of $\mathrm{C} 3$ and $\mathrm{C} 4$ proteins has been 

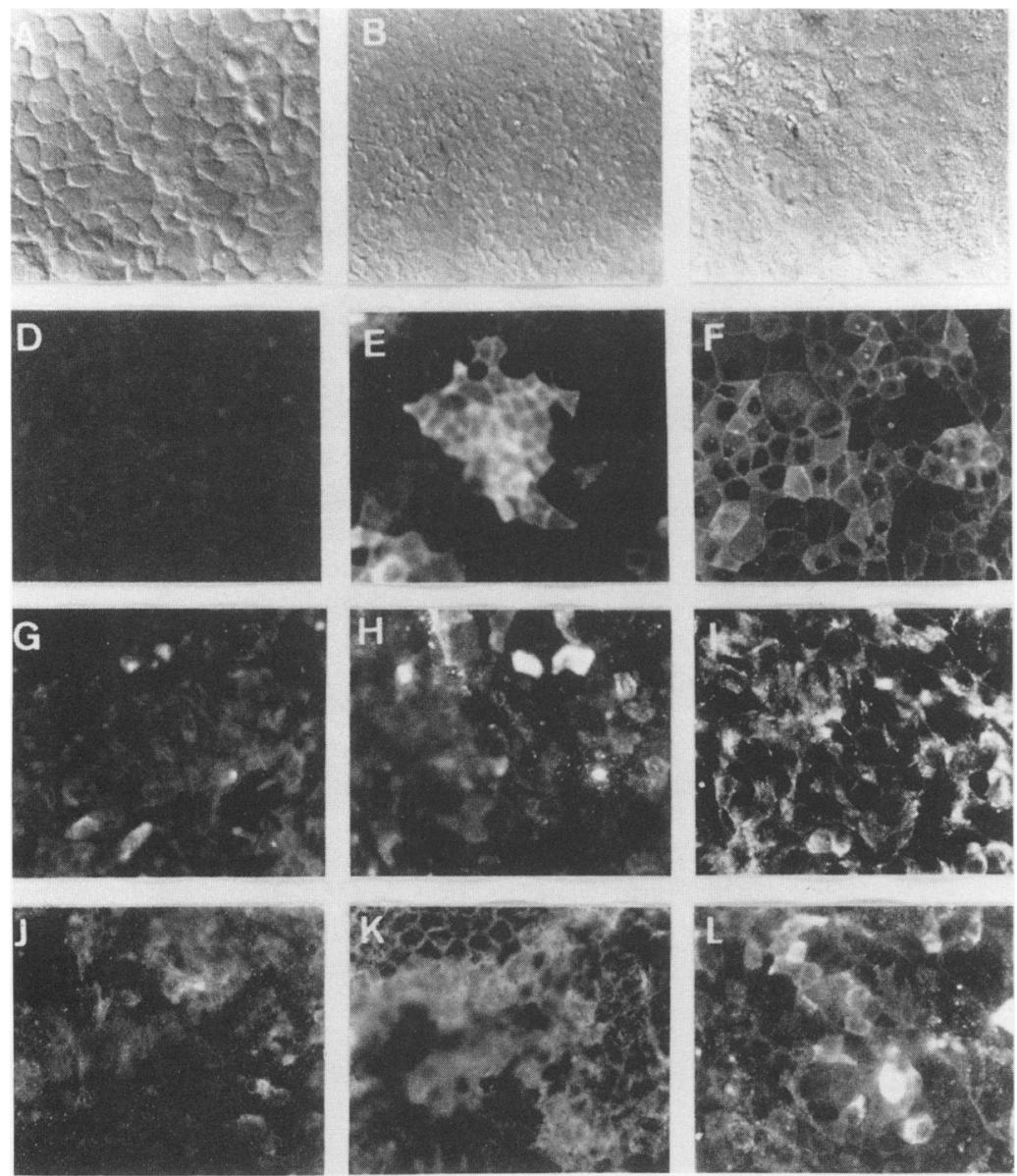

Figure 4: Expression of $C 3$ complement protein and $D A F$ as a function of the cell differentiation of the human cultured intestinal Caco-2 cells. ( $A, D, G, \mathcal{F})$ Caco-2 cells at day 5 in culture; ( $B, E, H, K)$ Caco-2 cells at day 10 in culture; $(C, F, I, L)$ Caco-2 cells at day 15 in culture. ( $A$ to $C$ ) Interference contrast micrograph of confluent cells. Indirect immunofluorescence labelling of sucrase-isomaltase $(D-F)$; complement $C 3$ protein $(G-I)$; and $D A F(\mathcal{F}-L)$. Note the growth related expression of SI. Complement $C 3$ and DAF were poorly expressed by the undifferentiated Caco-2 cells; the level of expression increases as a function of the days in culture.

seen. ${ }^{23}$ In the human intestine, cells differentiate during their migration along the crypt-villus axis. In an attempt to record the comparative expression of $\mathrm{C}$ complement proteins and regulatory $\mathrm{C}$ proteins in human intestinal cells as a function of the intestinal cell differentiation, we used a subset of cultured human colon adenocarcinoma cells. Indeed, there are similarities between differentiated adenocarcinoma cells and the small intestine. Taking into account the origin of these cells - that is, malignant cells originating from the colon ${ }^{15}$ and expressing the characteristics of fetal colon at midgestation - they seem to express features of the fetal colon, as the fetal colon expresses transient small intestinal differentiation during the mammalian development. Regardless of the limitations of these

TABLE II DAF acts as receptor for the C1845 E coli bearing the F1845 fimbrial adhesin in human cultured intestinal INT407, $T_{84}$, and Caco- 2 cells

\begin{tabular}{llll}
\hline & INT407 & $T_{84}$ & Caco-2‡ \\
\hline C1845 E coli & $5 \cdot 89(0 \cdot 5)$ & $5 \cdot 28(0 \cdot 3)$ & $5 \cdot 77(0 \cdot 3)$ \\
Incubation with anti-F1845 antibody & ND & ND & $2 \cdot 56(0 \cdot 4)^{\star \star \star}$ \\
Incubation with anti-DAF antibody & $1 \cdot 33(0 \cdot 4)^{\star \star \star}$ & $3 \cdot 76(0 \cdot 4)^{\star \star}$ & $3 \cdot 38(0 \cdot 4)^{\star \star}$ \\
Incubation after PIPLC cell treatment & $2 \cdot 47(0 \cdot 2)^{\star \star \star}$ & $3 \cdot 81(0 \cdot 3)^{\star \star}$ & $3 \cdot 71(0 \cdot 3)^{\star \star}$ \\
\hline
\end{tabular}

¥Caco-2 cells after 15 days in culture. ND - not determined. Each experiment was conducted in triplicate. The data represent mean (SEM) values of experiments from two or three successive
passages of cells. ${ }^{\star \star}$ Significant difference $(p<0 \cdot 01) ;{ }^{\star \star \star}$ highly significant difference $(p<0 \cdot 001)$ cellular models, they have provided useful tools to study the functions of mature enterocytes and mucus secreting cells of the small intestine, ${ }^{11}$ and to analyse the intestinal cell differentiation process. ${ }^{11} 12$

Activation of the complement system participates in the pathogenesis of intestinal disorders. ${ }^{29-31}$ Local activation of the $\mathrm{C}$ system has been seen in ulcerative colitis ${ }^{32}$ and Crohn's disease. ${ }^{33}$ Results presented here show that a panel of cultured human intestinal cells, such as INT407, $\mathrm{T}_{84}$, and HT-29 glc $^{-1+}$ cells, expressing different degrees of cell differentiation, synthetise the $\mathrm{C} 3$ and $\mathrm{C} 4$ complement proteins and the regulatory DAF. There were some differences, however, in the pattern of expression and staining intensity among the four cell lines. Indeed, the presence of DAF, C3, and C4 proteins was especially noticeable in cases of carcinoma cells, whereas it was lower in embryonic undifferentiated intestinal cells. In contrast, all these cells did not express the C5 and C5b-9 complement proteins and the CR1 receptor. As the cells lining the vascular compartment $^{1}$ and extravascular cells, ${ }^{21} 2224$ the intestinal cells develop a C complement regulatory system. It was noticed that the expression of $\mathrm{C}$ complement proteins in the colon adenocarcinoma cells was somewhat different from that seen in thyroid cancer cells, which expressed C5b-9 and CR1 together with C3d, S-protein, DAF, MCP, CR2, and protectin. ${ }^{24}$ We report that $\mathrm{C} 3$ and $\mathrm{C} 4$ expression increases as a function of the cell differentiation. It was particularly interesting to note that the expression of the regulatory DAF increases in parallel. As the Caco-2 cells mimics in vitro the differentiation of the enterocytes during their migration along the crypt-villus axis, ${ }^{11} 12$ this suggests that the intestinal cells in the tips of the villi could be more protected against inadvertent $\mathrm{C}$ complement damage than the cells at the base of the crypt.

Our results are also of interest with regard to intestinal microbial pathogenesis. Indeed, several findings suggest that microbial infections could be an inducing factor of inflammatory bowel disease. For example, this hypothesis is supported by the finding of an association of viruses, such as the Epstein-Barr virus interacting with a membrane cofactor regulating the complement activity, with acute episodes of exacerbations of chronic inflammatory bowel disease. ${ }^{34}$ Moreover, gut mucosal adherent pathogenic $E$ coli have been seen in patients with colitis. ${ }^{35}$ Involvement of adherent pathogenic $E$ coli in gut inflammatory disease was also suggested by Bilge et al, ${ }^{36}$ who saw inflamed mucosa in a pig model infected with the $E$ coli $\mathrm{C} 1845$ strain. This diarrhoeagenic $E$ coli belongs to a family of uropathogenic and diarrhoeagenic $E$ coli $^{78}$ colonising different parts of the human urinary tract $^{3738}$ and the intestine. ${ }^{38}$ Considering the C regulatory function of DAF, Nowicki et al ${ }^{9}$ postulated that interaction of these pathogenic $E$ coli with the cell membrane associated DAF could lead to an immunopathological lesion in the target cells. Our results are consistent with 
this hypothesis. Indeed, we show that $E$ coli harbouring the fimbrial F1845 adhesin interacts in part with the membrane bound DAF to colonise the apical surface of undifferentiated, poorly differentiated, and fully differentiated human cultured intestinal cells in which C components were expressed. In consequence, it is possible that the colonisation of the intestine by this pathogenic $E$ coli could promote inflammation of mucosa through a local $\mathrm{C}$ system, resulting from the blockage of the regulatory function of DAF by adhesinDAF interaction.

This work was supported by grants from: Institut National de la Santé et de la Recherche Médicale, Fondation pour la Recherche Médicale, Association pour la Recherche sur le ship (MESR).

1 Nicholson-Weller A. Decay accelerating factor (CD55). Curr Top Microbiol Immunol 1992; 178: 360-8.

2 Andoh A, Fujiyama Y, Bamba T, Hosoda S. Differential cytokine regulation of complement $\mathrm{C} 3, \mathrm{C} 4$, and factor $\mathrm{B}$ synthesis in human intestinal epithelial cell line, Caco-2. 7 Immunol 1993; 151: 4239-47.

3 Molmenti EP, Ziambaras T, Perlmutter DH. Evidence for an accute phase response in human intestinal epithelial cells. $\mathcal{F}$ Biol Chem 1993; 268: 14116-24.

4 Medof ME, Walter EI, Rutgers J, Knoweles DM, Nussenzweig V. Identification of the complement decayaccelerating factor (DAF) on epithelial and glandular cells and in body fluid. $\mathcal{F}$ Exp Med 1987; 165: 848-64.

5 Kernéis S, Bilge S, Fourel V, Chauviere G, Coconnier MH, Servin AL. Use of purified F1845 fimbrial adhesin to Servin AL. Use of purified F1 845 fimbrial adhesin to
study localization and expression of receptors for diffusely study localization and expression of receptors for diffusely adhering Escherichia coli (DAEC) during enterocytic differentiation of human colon carcinoma cell lines HT-29 and Caco-2 in culture. Infect Immun 1991; 59: 4013-8.
Kernéis S, Gabastou JM, Bernet-Camard MF, Coconnier MH, Nowicki B, Servin AL. Human cultured intestinal cells express attachment sites for uropathogenic Escherichia coli bearing adhesins of the Dr adhesin family. FEMS Microbiol Lett 1994; 119: 27-32.

7 Nowicki B, Moulds J, Hull R, Hull S. A hemagglutinin of uropathogenic Escherichia coli recognizes the Dr blood group antigen. Infect Immun 1988; 56: 1057-60.

8 Nowicki B, Labigne A, Moseley S, Hull R, Hull S, Moulds J. The Dr hemagglutinin, afimbrial adhesins AFA-I, AFAJ. The Dr hemagglutinin, afimbrial adhesins AFA-I, AFAdiarrhea-associated Escherichia coli belong to a family of diarrhea-associated Escherichia coli belong to a family of
hemagglutinins with the $\mathrm{Dr}$ receptor recognition. Infect Immun 1990; 58: 279-81.

9 Nowicki B, Hart A, Coyne KE, Lublin DM, Nowicki S. Short consensus repeat-3 domain of recombinant decayaccelerating factor is recognized by Escherichia coli recombinant $\mathrm{Dr}$ adhesin in a model of cell-cell interaction. $\mathcal{F}$ Exp Med 1993; 178: 2115-21.

10 Kedinger M. In: Campbell FC, ed. Small bowel enterocyte, culture and transplantation. Austin: RG Landes, 1994: 1-25.

11 Zweibaum A, Laburthe M, Grasset E, Louvard D. In: Zweibaum A, Laburthe M, Grasset E, Louvard D. In:
Schultz SJ, Field M, Frizell RA, eds. Handbook of Schultz SJ, Field M, Frizell RA, eds. Handbook of
Physiology. The Gastrointestinal System. New York: Alan Liss, 1991: 223-52.

12 Louvard D, Kedinger M, Hauri HP. The differentiating intestinal epithelial cell: establishment and maintenance of functions through interactions between cellular structures. Ann Rev Cell Biol 1992; 8: 157-95.

13 Pinto $M$, Robine-Leon S, Appay MD, Kedinger $M$, Triadou N, Dussaulx E, et al. Enterocyte-like differentiation and polarization of the human colon carcinoma cell line Caco-2 in culture. Biol Cell 1983; 47: 323-30.

14 Lesuffleur T, Kornowski A, Augeron C, Dussaulx E, Barbat A, Laboisse A, et al. Increased growth adaptability to 5fluorouracil and methotrexate of HT-29 subpopulations
selected for their commitment to differentiation. Int $\mathcal{f}$ selected for their commit
Cancer 1991; 49: 731-7.

15 Fogh J, Fogh JM, Orfeo T. One hundred and twenty seven cultured human tumor cell lines producing tumors in nude mice. $\mathcal{F}$ Natl Cancer Inst 1977; 59: 221-6.
16 Zweibaum A, Pinto M, Chevalier G, Dussaulx E, Triadou $\mathrm{N}$, Lacroix B, et al. Enterocytic differentiation of a subpopulation of the human colon tumor cell line HT-29 selected for growth in sugar-free medium and its inhibiselected for growth in sugar-free medium and
tion by glucose. $\mathcal{F}$ Cell Physiol 1985; 122: 21-9.

17 Dharmsathaphorn K, McRoberts JA, Mandel KG, Tisdale $\mathrm{LD}$, Masui $\mathrm{H}$. A human colonic tumor cell line that maintains vectorial electrolyte transport. Am $\mathcal{F}$ Physiol 1984; 246: G204-8.

18 Madara JL, Stafford J, Dharmsathaphorn K, Carlson S. Structural analysis of a human intestinal epithelial cell line. Gastroenterology 1987; 92: 1133-44.

19 Barret KE. Positive and negative regulation of chloride secretion in T84 cells. Am f Physiol 1993; 65: C859-68.

20 Nicholson-Weller A. Deficiencies of the decay accelerating factor (DAF) and the C8-binding protein in paroxysmal nocturnal haemoglobinuria. Baillières Clin Immunol Allergy nocturnal haemog

21 Ichida S, Yuzawa Y, Okada H, Yoshioka I, Matsuo S. Localization of the complement regulatory proteins in the normal human kidney. Kidney Int 1994; 46: 89-96.

22 Matsuo S, Nishikage HG, Yoshida F, Nomura A, Piddlesden SJ, Morgan BP. Role of CD59 in experimental glomerulonephritis in rats. Kidney Int 1994; 46: 191-200.

23 Law SKA, Reid KBM. In: Male D, Rickwood D, eds. Complement. Oxford: IRL Press, 1989: 9-27.

24 Yamakawa $M$, Yamasa $K$, Tsuge $T$, Ohrui $H$, Ogata $T$, Dobashi $\mathrm{T}$, et al. Protection of thyroid cancer cells by complement-regulatory factors. Cancer 1994; 73: 2808-17.

25 Brooimans RD, Stegmann AP, Van Dorp WT, Van Der Ark AA, Van Der Woude FJ, Van Es LA, et al. Interleukin 2 mediates stimulation of complement C3 biosynthesis in human proximal tubular epithelial cells. $f$ Clin Invest 1991; 88: 379.

26 Morris KM, Colten HR, Bing DH. A quantitative comparison of its biosynthesis in culture by human epithelial and mesenchymal cells. F Exp Med 1978; 148: 1007-19.

27 Rothman BL, Despins AW, Kreuter DL. Cytokine regulation of $\mathrm{C} 3$ and $\mathrm{C} 5$ production by the human type II pneumocyte cell line, A549. F Immunol 1990; 145: 592-8.

28 Strunk RC, Eidlen DM, Mason RJ. Pulmonary alveolar type II epithelial cells synthesize and secrete proteins of the classical and alternative complement pathways. $\mathcal{F}$ Clin Invest 1988; 81: 1419-26.

29 Gallagher RB, Kelly CP, Neville S, Sheils O, Weir DG, Feighery CF. Complement activation within the coeliac small intestine is localised to Brunner's glands. Gut 1989; 30: $1568-73$.

30 Halstensen TS, Mollnes TE, Brandtzaeg P. Persistent complement activation in submucosal blood vessels of active inflammatory bowel disease: immunohistochemical evidence. Gastroenterology 1989; 97: 10-20.

31 Halstensen TS, Hatvum M, Scott S, Fausa O, Brandtzaeg $P$. Association of subepithelial deposition of activated complement and immunoglobulin $G$ and $M$ response to gluten in celiac disease. Gastroenterology 1992; 102: gluten

32 Halstensen TS, Mollnes TE, Garred P, Fausa O, Brandtzaeg P. Epithelial deposition of immunoglobulin $\mathrm{G} 1$ and activated complement (C $3 \mathrm{~b}$ and terminal complement complex) in ulcerative colitis. Gastroenterology 1990; 98: 1264-71.

33 Ahrenstedt O, Knutson L, Nilsson B, Nilsson-Ekdahl K, Odlind B, Hällgren R. Enhanced local production of complement components in the small intestines of patients with Crohn's disease. $N$ Engl f Med 1990; 322: patients

34 Kangro HO, Chong SKF, Hardiman A, Heath RB, WalkerSmith JA. A prospective study of viral and mycoplasma infections in chronic inflammator
Gastroenterology 1990; 98: 549-53.

35 Burke DA, Axon ATR. Hydrophobic adhesin of E coli in ulcerative colitis. Gut 1988; 29: 41-3.

36 Bilge SS, Apostol Jr JM, Fullner KJ, Moseley SL. Transcriptional organization of the F1845 fimbrial adhesin determinant of Escherichia coli. Mol Microbiol 1993; 7: 993-1006.

37 Nowicki B, Holthofer H, Saraneva T, Rhen M, VäisänenRhen V, Korhonen TK. Location of adhesion sites for P-fimbriated and O75X-positive Escherichia coli in the human kidney. Microb Pathog 1986; 1: 169-80.

38 Nowicki B, Truong L, Moulds J, Hull R. Presence of Dr receptor in normal human tissues and its possible role in the pathogenesis of ascending urinary tract infection. $\mathrm{Am}$ f Pathol 1988; 133: 1-4. 